\title{
A BRANDING IRON FOR MARKING HISTOLOGY TISSUES BY
}

\author{
I. M. TUCK
}

From the North-Western Group Laboratory, London

(RECEIVED FOR PUblication MARCH 30, 1953)

Every histologist experiences from time to time the annoyance of having sections cut from the wrong face of a piece of tissue. Even the timehonoured method of marking the surface to be blocked uppermost by shaving off the edge of one side occasionally fails, especially with the thinner slices that tend to be cut nowadays for the automatic tissue processors. The branding iron here described is designed to overcome this difficulty.

The head consists of a block of copper, $2 \times 1.5$ $\mathrm{cm}$. and $0.75 \mathrm{~cm}$. thick, with a tapered tongue $2 \mathrm{~cm}$. long projecting from the centre of one of the longer sides. On one surface diagonal cuts in opposite directions are made with a hacksaw and these are further opened with the edge of a half round file, so leaving a pattern of diamond-shaped projections.

The tapered tongue is riveted into the split end of a piece of steel rod which has a wooden handle at the other extremity.

In use the head is heated in a bunsen flame to a dull red and the patterned surface momentarily applied to the face of the tissue opposite to that from which sections are to be cut. The period of contact is so short that the specimen suffers no harm; the marking is distinct and is unaltered by subsequent processing.

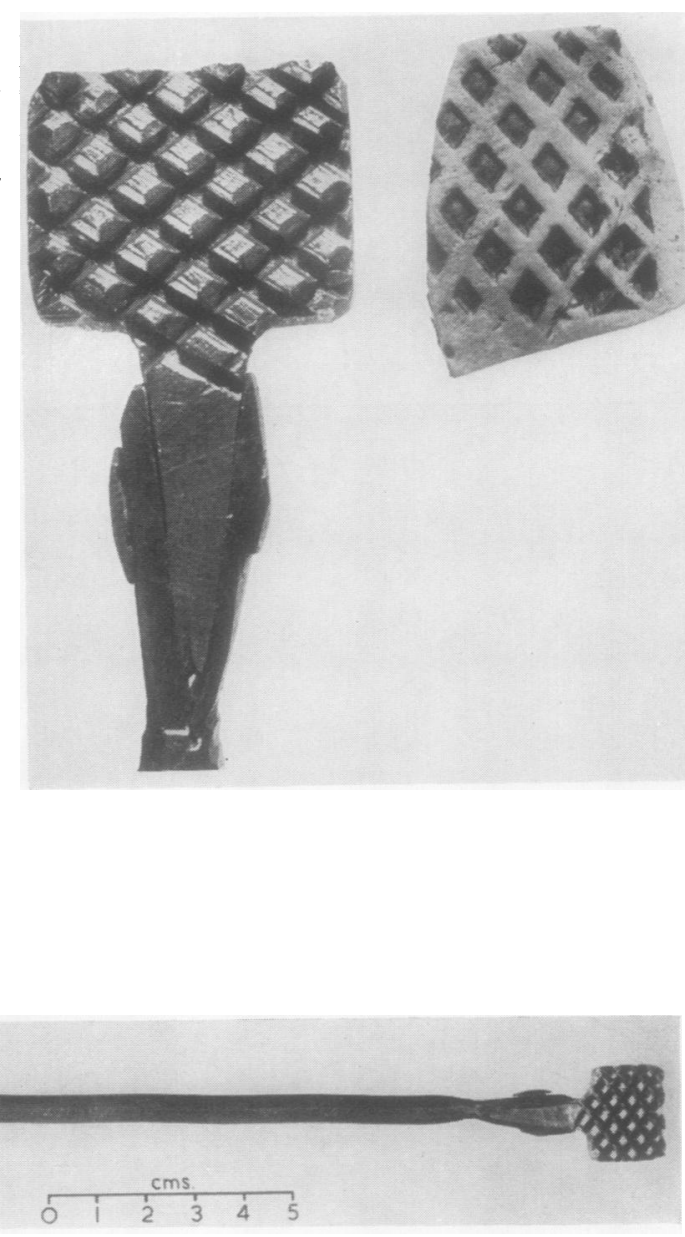

